\title{
Performance of Palm Oil Mill Effluent (POME) as Biodiesel Source Based on Different Ponds
}

\author{
Deodata Leela ${ }^{1, *}$, Syukri M. Nur ${ }^{1,2}$, Erkata Yandri ${ }^{1,2}$ and Ratna Ariati ${ }^{1,2}$ \\ ${ }^{1}$ Graduate School of Renewable Energy, Darma Persada University, Jl. Raden Inten 2, Pondok Kelapa, East Jakarta 13450 \\ ${ }^{2}$ Centre of Renewable Energy Studies, Darma Persada University, Jl. Raden Inten 2, Pondok Kelapa East Jakarta 13450
}

\begin{abstract}
The purpose of this paper is to prove that waste palm oil industry (POME) can be used as raw material (source of energy) for biodiesel. In the production process, palm oil mill produced large amounts of waste. The provision of a shelter pond system is a temporary solution from palm oil mill to relocate the liquid waste. With BOD content with range 25,625 to $39,616.7 \mathrm{mg} / \mathrm{l}$ and COD content with range $117,333.3$ to $146,333.3 \mathrm{mg} / \mathrm{l}$, this condition will generate a serious problem for environmental pollution. Therefore, it is important to test the characteristics of waste oil from each pond. The hexane solvent extraction method is used to separate the oil from the liquid waste. The first pond contains $51.3 \%$ water, $21 \%$ oil, $2 \%$ sludge \& sediment and $5.6 \%$ free fatty acids. The second pond contains $86.7 \%$ water, $16.1 \%$ oil, $2.4 \%$ sludge \& sediment and $8 \%$ free fatty acids. The third pond contains $74 \%$ water, $6.8 \%$ oil, $3.1 \%$ sludge \& sediment and $12.2 \%$ free fatty acid and the fourth pond contains $78.7 \%$ water, $3.7 \%$ oil, $2 \%$ sludge \& sediment and $13.3 \%$ free fatty acids. Based on the results of this research, the characteristics of POME and its oil losses are the fraction of oil wasted from Crude Palm Oil (CPO) processing, whereas CPO has characteristics as a raw material for Biodiesel. POME should be processed into biodiesel since the liquid waste is discarded from palm oil mill, so there is no need a big land to make waste storage ponds.
\end{abstract}

\section{Introduction}

Indonesia has a great potential to utilize biomass energy from the palm oil industry which has $8 \%$ growth per year [1]. However, behind this potential, there is a negative impact of liquid waste that is often called Palm Oil Mill Effluent (POME). POME is an oily liquid waste derived from condensate decomposition, water hydrocyclones and mud separators. Though non-toxic, POME is not maintained properly will cause unpleasant odors around the plant. Then, the liquid waste seepage will cause water and soil contamination around the factory area and release large amounts of methane gas and other hazardous gases, leading to greenhouse gas emissions [2].

To resolve this problem, palm oil mill management has provided a number of waste storage ponds, or so-called ponds. The number of ponds provided depends on the amount of liquid waste available. The longer the factory operate, the number of ponds provided will also be more and more. Apparently, this solution is only temporary.

One of the best alternative solutions is how to turn POME into energy in the conformation of biodiesel. The cost of production process is a major constraint related to the commercialization of biodiesel production. The use of low cost feedstock is an alternative way of improving the economic value of biodiesel production and its commercial production industry scale [3]. This solution is an effort to supply second generation biofuel and is also expected to produce biodiesel, but not conflict with the provision of food [4]. As a first step to reach the solution is to identify the source of raw materials from ponds available around the palm oil mill. The question to be answered in this study is which pond the best source with the highest oil content.

So far, POME has not been widely used and discharged into the rivers that pollute the environment. In average, POME contains BOD (Biologycal Oxygen Demand) has range from 8,200 to $35,000 \mathrm{mg} / \mathrm{L}$ and COD (Chemical Oxygen Demand) ranged from 15,103 to $65,100 \mathrm{mg} / \mathrm{L} \mathrm{[5]}$. The liquid waste management of palm oil mills in Indonesia is based on waste water quality standards, as shown in Table 1.

\footnotetext{
Corresponding author: deodata.leela@gmail.com
} 
Table 1. Waste Water Quality Standard of Palm Oil Mill [6]

\begin{tabular}{lc}
\hline \multicolumn{1}{c}{ Parameter } & The Highest Level \\
\hline $\mathrm{BOD}_{5}(\mathrm{mg} / \mathrm{L})$ & 100 \\
$\mathrm{COD}(\mathrm{mg} / \mathrm{L})$ & 350 \\
TSS $(\mathrm{mg} / \mathrm{L})$ & 250 \\
Oil \& grease $(\mathrm{mg} / \mathrm{L})$ & 25 \\
Nitrogen Total $(\mathrm{mg} / \mathrm{L})$ & 50 \\
$\mathrm{pH}$ & $6,0-9,0$ \\
The highest of waste discharge & 2,5 \\
$\left(\mathrm{~m}^{3} /\right.$ ton CPO) & \\
\hline
\end{tabular}

Currently, waste water treatment from palm oil mill still uses ponding system. This method requires a lot of land for waste storage and it takes a long time for liquid waste to reach the standard value of waste water, as determined by the government. Fig. 1 describes the waste treatment technique scheme using a pond system, which is generally carried out by the Indonesian palm oil mill.

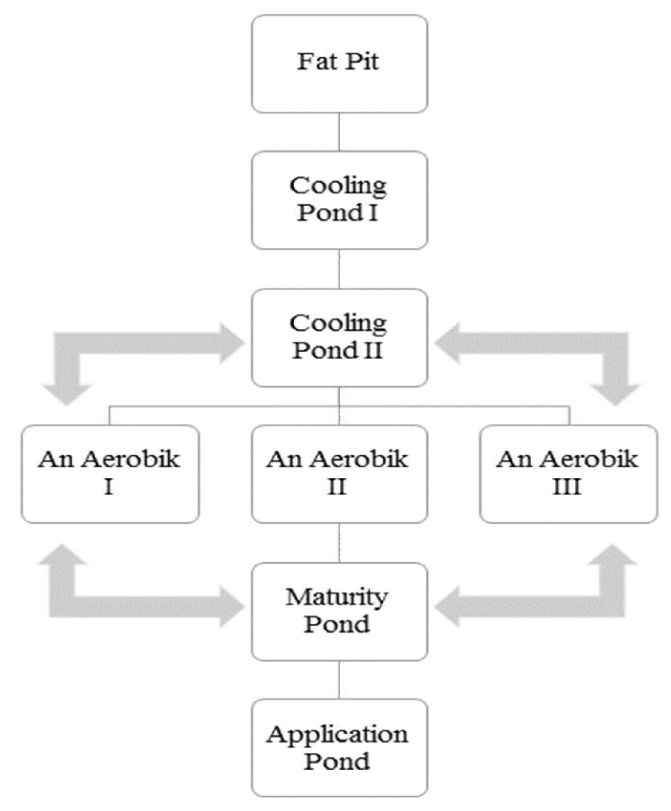

Fig. 1. Ponding system of POME

With a high COD content in POME, it has the potential to produce methane gas to be converted into electrical energy through a series of purification steps. In addition, with the fermentation process, POME can also be used as a liquid fertilizer for oil palm plantation itself in the area of palm oil factory. This research concentrates on processing POME into biodiesel.

The oil and fat content in POME is about 6,000 $\mathrm{mg} / \mathrm{L}$ [7]. Oil and grease in POME can be extracted into biodiesel feedstock, because it is classified as low-grade oil, high free fatty acid content at very low price, but it is abundant. Several methods have been used to separate the remaining oil from POME, including biological-chemical adsorption methods and solvent extraction. This research uses solvent extraction method, because it is easy to remove solvent to get oil [8]. Currently, the investigation of new renewable raw materials for biodiesel synthesis is one of the popular research areas in the biodiesel industry [9].

The purpose of this research is to know the residual oil characteristics of four selected POME reservoirs as biodiesel sources, including; water content, oil content, free fatty acid content, kinematic viscosity@40 ${ }^{\circ} \mathrm{C}$, acid number, sludge and sediment content, iodine value, saponification value and unsaponification matter [10][11][12][13][14][15].

\section{Methodology}

\section{a. Sources of Raw Material}

POME samples were taken from the area of Cikasungka Palm Oil Mill, Bogor Regency, West Java, Indonesia. This plant has a capacity of 60 tons FFB/hour and operates 20 hours/day with $50 \%$ of liquid waste, predicted POME about 480 tons/day.

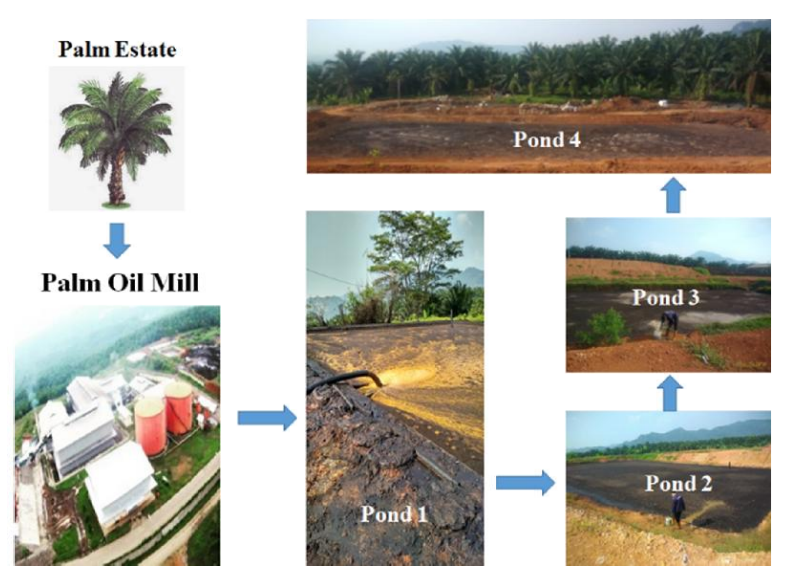

Fig. 2. Product flow and location of sampling

Around the location of palm oil mill, there are seven liquid waste storage ponds. Pond \#1 is just a few meters from the factory. Factory waste is channeled directly to pond \#1 called "fat pit". Pond \#1 and \#3 (cooling pond) are located about 6 meters from pond $\# 1$. Pond $\# 4, \# 5, \# 6$ and $\# 7$ as anaerobic ponds are under ponds $\# 1, \# 2$, \#3. Fig. 2 shows the flow of waste production from the plant to the disposal ponds and sampling sites.

The chemicals and solution used in this study were: n-hexane, n-heptane, pentane, toluene, isoprophyl alcohol (isopropanol), $0,1 \mathrm{~N} \mathrm{KOH}, \mathrm{HCl}$ $0,45 \mathrm{~N}$, methanol $\left(\mathrm{CH}_{3} \mathrm{OH}\right)$, ethanol $\left(\mathrm{C}_{2} \mathrm{H}_{5} \mathrm{OH}\right)$, potassium iodide $(\mathrm{KI})$, fenolphthalein indicator, potassium dichloromate $\left(\mathrm{K}_{2} \mathrm{Cr}_{2} \mathrm{O}_{7}\right)$, potassium mercuric iodide $\left(\mathrm{K}_{2} \mathrm{HgI}_{4}\right)$, water (aquades), $\mathrm{Na}_{2} \mathrm{~S}_{2} \mathrm{O}_{3}$, hydrocloric acid $(\mathrm{HCl})$, sodium thiosulfate $\left(\mathrm{Na}_{2} \mathrm{~S}_{2} \mathrm{O}_{3}\right)$ and oleic acid $\left(\mathrm{C}_{18} \mathrm{H}_{34} \mathrm{O}_{2}\right)$.

\section{b. Sampling}

The sampling point is shown in fig. 3. From the seven ponds, four ponds are selected, namely pond $\# 1$ to 
pond \#4. The sample is taken at 3 points on the selected pond, from inlet, middle and outlet. Thus, there are 12 samples for the four ponds.

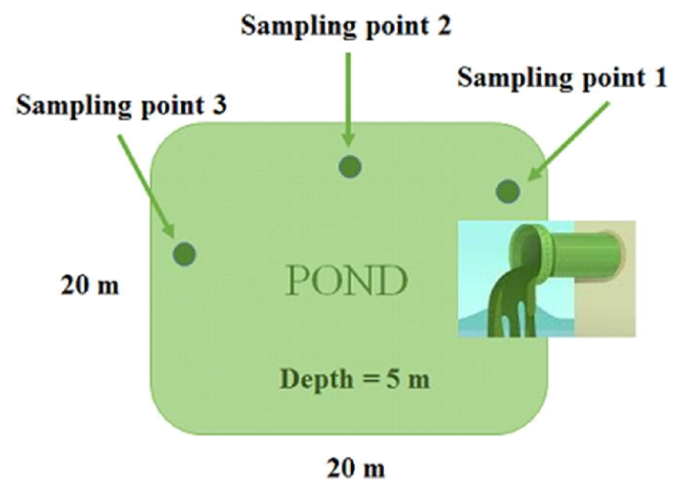

Fig. 3. Sampling Point

\section{c. Measurement}

To understand the characteristics of POME, there are 2 stages of measurement. First, to measure parameters of POME waste water, as follows:

\section{i. Waste Water Quality Standard}

Wastewater quality standards shall be limits or levels of pollutants and / or the amount of pollutant elements which are tolerated in the waste water to be discharged or released into a water medium from a business and / or activity. The standard of waste of the palm oil industry is regulated by the Regulation of Ministry of Environment and Forestry No.5/2014.

pH: In the management of liquid waste, $\mathrm{pH}$ value indicator has a very important role as a parameter of waste water quality standards. $\mathrm{pH}$ indicates acid or base content in solution. Through the chemical aspect, the water atmosphere affects biological and microbiological life. The $\mathrm{pH}$ value is determined at the time of sampling in the pond using the electrometric APHA 4500-H+B method with the multi-parameter PCTester 35. The tool is immersed into the samples taken and then recording the reading without lifting the appliance first.

Temperature: The sample temperature is measured at the same time as the $\mathrm{pH}$ at the sample. Temperature measurements use the APHA 2550 method with a mercury thermometer having scale up to $110^{\circ} \mathrm{C}$.

BOD 5 : Biological Oxygen Demand (BOD) is an empirical analysis that attempts to globally approach microbiological processes that actually occur in water. BOD checks are needed to determine the pollution load due to industrial waste water. Measurement of BOD is using APHA method 5210. BOD examination is based on the oxidation reaction of organic substances with oxygen in the water and the process takes place due to the presence of aerobic bacteria. The oxidation results will form carbon dioxide, water and ammonia. The oxidation reaction can be written as follows:

$$
C_{n} H_{a} O_{b} N_{c}+\left(n+\frac{a}{4}-\frac{b}{2}-\frac{3 c}{4}\right) O_{2} \stackrel{\text { bactery }}{\longrightarrow} n \mathrm{CO}_{2}+\left(\frac{a}{2}-\frac{3 c}{2}\right)+\mathrm{H}_{2} \mathrm{O}+c N \mathrm{H}_{3}
$$

The biological reaction on the BOD test was performed at an incubation temperature of $20{ }^{\circ} \mathrm{C}$ and was carried out for 5 days, to have a full-term $\mathrm{BOD}_{5}{ }^{20}$ value.

COD: Chemical Oxygen Demand (COD) is the amount of oxygen in magnesium peroxide $\left(\mathrm{MgO}_{2}\right)$ required oxidizing organic matter contained in one $\mathrm{ml}$ of water sample, where oxidation of $\mathrm{K}_{2} \mathrm{Cr}_{2} \mathrm{O}_{7}$ is used as an energy source (oxidizer), with the following reaction:

$$
\mathrm{C}_{a} \mathrm{H}_{b} \mathrm{O}_{\mathrm{C}}+\mathrm{Cr}_{2} \mathrm{O}_{7}^{2-}+\mathrm{H}^{+} \frac{\Delta E}{\mathrm{Ag}_{2} \mathrm{SO}_{4}}>\mathrm{CO}_{2}+\mathrm{H}_{2} \mathrm{O}+\mathrm{Cr}^{3^{+}}
$$

The value of COD is an indicator for water pollution by organic substances which can naturally be oxidized through microbiological processes and results in reduced oxygen dissolved in water. Measurement of COD is using APHA method 5220.

Total Suspended Solid: The precipitated solid is a substance in the suspense that is settled after a certain time due to the influence of gravity. The APHA 2540 method is used to determine the suspended residue contained in the water test sample by gravimetric. The sample is filtered with a paper filter, escaped liquid, then dried at $105{ }^{\circ} \mathrm{C}$, then cooled in a desiccator to balance the temperature and weighed.

$$
\text { mg TSS per liter }=\frac{(A-B) \times 1000}{\text { sample test volume }}
$$

Where; $A$ is the weight of filter paper + dry residue (mg), $B$ weight of filter paper (mg)

NH3: Ammonia (NH3) is a nitrogen compound that becomes $\mathrm{NH}_{4}^{+}$at a low $\mathrm{pH}$ and is called ammonium. Ammonia itself is reduced ( -3$)$. Ammonia comes from organic substances $\left(\mathrm{H}_{\mathrm{a}} \mathrm{O}_{\mathrm{b}} \mathrm{C}_{\mathrm{c}} \mathrm{N}_{\mathrm{d}}\right)$. In wastewater, $\mathrm{NH} 3$ can be microbiologically processed by nitrification into $\mathrm{NO}_{2}$ and $\mathrm{NO}_{3}$ nitrate, according to the reaction as follows:

$$
\begin{gathered}
2 \mathrm{NH}_{4}^{+}+3 \mathrm{O}_{2} \stackrel{\text { bactery }}{\longrightarrow} 2 \mathrm{NO}_{2}^{-}+4 \mathrm{H}^{+}+2 \mathrm{H}_{2} \mathrm{O}+\text { energy } \\
2 \mathrm{NO}_{2}^{+}+\mathrm{O}_{2} \stackrel{\text { bactery }}{\longrightarrow} 2 \mathrm{NO}_{3}^{-}+\text {energy }
\end{gathered}
$$

Ammonia nitrogen can be determined by distillation. In distillation process containing ammonia, it is accommodated by an absorbent solution that binds the ammonia. Then, Ammonia is determined by the Nessler method (APHA 4500) which consists of a chemical analysis using a 
spectrophotometer. The Nessler $\mathrm{K}_{2}, \mathrm{Hg}, \mathrm{I}_{4}$ reagents will react with $\mathrm{NH}_{3}$ in an alkaline solution, according to the reaction below:

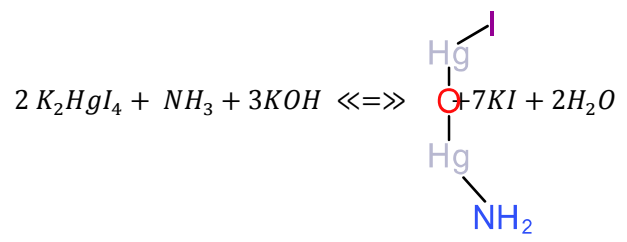

Oil and Grease: The gravimetric method (APHA $5520 \mathrm{~B})$ is applied to determine the oil and grease content in wastewater samples. This method also handles certain emulsions, non-volatile substances and other substances extracted by solvents, such as sulfur compounds, certain organic dyes and chlorophyll. This method can not be used to measure fractions having a boiling point less than $70{ }^{\circ} \mathrm{C}$, when using a trichlorotriflouroethane solvent; or, when using a n-hexane mixed solvent with methyl tert buthyl ether (80:20) at a boiling point below $85{ }^{\circ} \mathrm{C}$. The amount of oil and grease can be calculated by the following formula;

$$
\text { Oil and Grease }=\frac{(A-B) \times 1000}{\text { sample test volume }}
$$

Where; $A$ is the weight of erlenmeyer + sample extraction [mg], $B$ is the weight of the empty Erlenmeyer [mg].

\section{ii. Sludge Palm Oil Characteristic}

The second measurement was performed to determine the composition, oil volume, organic acid content, and oil characteristics of sludge palm oil.

\subsubsection{Testing Before Pre-Treatment}

Pre-Treatment testing is performed to determine the composition of POME, including;

Water Content: Visually, the water content of POME is quite large, so the method used to measure the water content is by ASTM D95 method by distillation. Five $\mathrm{ml}$ samples of POME are inserted into the weighing bottle, and then dried by oven at $105{ }^{\circ} \mathrm{C}$ to a constant weight. The weight loss of the sample is expressed as the weight of the evaporated water from the sample [10].

Oil Content: sample was added to $10 \mathrm{ml}$ of toluene in a centrifuge tube, and then stirred at $4000 \mathrm{rpm}$ for 30 minutes. After that, the sample is divided into two phases, the sample is heated at $105{ }^{\circ} \mathrm{C}$ for 2 hours before the sample is weighed. The oil content can be calculated by the following equation:

$$
\text { Oil content }=\frac{B-A}{C(1 g r)} \times 100 \%
$$

Where; $B$ is final weight of sample, $A$ is weight of empty tube centrifuge, $C$ is weight of initial sample [1gr].

Sludge and Sediment: Sludge and sediment content was measured by ASTM D473 method. The process is, the sample is weighed at $10 \mathrm{gr}$ and added $10 \mathrm{ml} \mathrm{n}$ heptane, and then filtered with Whatman filter paper, weighed the empty weight to obtain the sediment sample. Then, heated at $110{ }^{\circ} \mathrm{C}$ for 1 hour, then cooled and weighed.

$$
\text { SLudge and Sediment }=\frac{B-A}{C(10 \mathrm{gr})} \times 100 \%
$$

Where; $B$ is final weight of sample, $A$ is weight of empty whatman paper, $C$ is weight of initial sample in $10 \mathrm{gr}$.

\subsubsection{Pre-Treatment}

Pre-Treatment is performed to separate oil with water from mud and sediment. This is to obtain the oil fraction by using solvent extraction method with nhexane [16][17].

Oil losses: $1000 \mathrm{ml}$ POME was placed into $3000 \mathrm{ml}$ glass, and then $1000 \mathrm{ml}$ of $\mathrm{n}$-hexane was added and stirred. Wait until the sediment falls and the oil that blends with the mud rises up and dissolves with the hexane. Hexane is an organic compound made of carbon and hydrogen with the chemical formula $\mathrm{C}_{6} \mathrm{H}_{14}$ which has a boiling point between $50-70{ }^{\circ} \mathrm{C}$. Hexane is a non-polar solvent, which is insoluble in water, but soluble in oil. Hexane-dissolved oil is poured into Erlenmeyer flask, separated by filter paper for approximately 15 minutes. After filtration, the solution is heated to $100{ }^{\circ} \mathrm{C}$ for about 1 hour to evaporate the hexane solution involved in filtration.

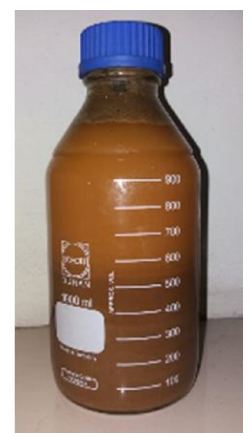

(a)

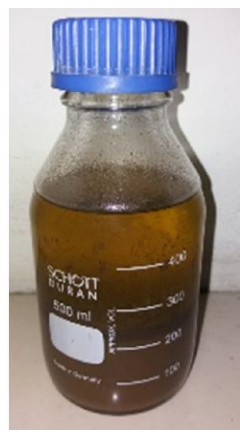

(b)

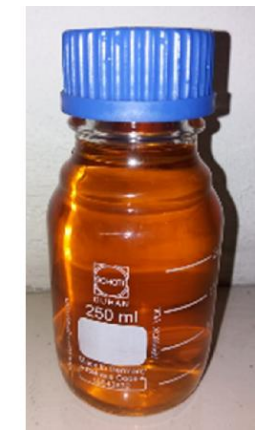

(c)
Fig. 4. Pre-Treatment of POME

Fig. 4(a) is POME sample taken from a pond. Fig. $4(b)$ is the result of a pre-treatment POME sample given a hexane solution with a ratio between sample: 
hexane being 1:1. Fig. 4(c) is a filtered sample in which the oil is still homogeneously combined with hexane.

Carboxylic acid: are hydrocarbon derivatives containing a carboxyl $(\mathrm{COOH})$ moiety [18]. One of the carboxylic acids present in palm oil is palmitic acid [19]. The method used is IR Spectra [20].

\subsubsection{Testing after Pre-Treatment}

Pre-Treatment testing is performed to determine the characteristics of oil losses, as extracts from POME, which include:

Kinematic Viscosity: Oil flow power that is affected by gravity and parameters, measured using ASTM D445 method. The Ostwald viscometer was filled with $5 \mathrm{ml}$ of sample, placed in bath water $40{ }^{\circ} \mathrm{C}$ and left for 10 minutes then measured the time required by the sample to pass the distance between two marks on the viscometer. The viscosity value is calculated using the formula:

$$
\frac{\eta}{\eta 0}=\frac{t d}{t 0 d 0}
$$

Where; $\eta$ and $\eta 0=$ viscosity of the solution and solvent, $t$ dan $t 0=$ flow time of solution and solvent

Free Fatty Acid: Free fatty acids are unrestricted fatty acids as triglycerides. Free fatty acids are produced by hydrolysis and oxidation processes, usually joined with neutral fats. To measure free fatty acid was done by AOCS $\mathrm{Ca} 5 \mathrm{a}-40$ method. Determination of free fatty acid value, obtained by the following formula:

$$
\% \text { Free Fatty Acid }=\frac{25,6 \times N \times V}{W}
$$

Where; $V$ is the volume of titration solution used [ml], $N$ is the normality of the titration solution, $W$ is the sample weight [gr], 25.6 is the constant to calculate the acid content as free fatty palmitic acid.

Total Acid Number: is the quantity of acid numbers in a sample. ASTM D974 method is used to get the value of acid number. Two grams of sample were fed into the Erlenmeyer flask, then $10 \mathrm{ml}$ of ethanol was then titrated using $0.1 \mathrm{~N} \mathrm{KOH}$ solution with $\mathrm{pp}$ indicator. The acid number is calculated by the formula:

Acid Value $=\frac{b \times N \mathrm{KOH} \times 40}{W} \mathrm{mg} \mathrm{KOH/gr} \mathrm{sample}$

Where; $b$ is $\mathrm{KOH}$ in the volume of alcohol required in the titration [ml], $N$ is normality of $\mathrm{KOH}, W$ is sample weight [gr].

Iodine Value: is a number to measure the degree of unsaturation in fatty acids. This is expressed by the number of grams of iodine absorbed by 100 gr of fat.
The iodine number depends on the amount of unsaturated fatty acids in the oil. The method used is AOCS Cd 1-25. Samples weighing 0.2 gr were included in $250 \mathrm{ml}$ erlenmeyer, added $7 \mathrm{ml}$ of chloroform, $8 \mathrm{ml}$ hubl A (2.5 gr of iodine dissolved in $50 \mathrm{ml}$ of ethanol) and $8 \mathrm{ml}$ of hubl B (3 gr of mercury chloride dissolved into $50 \mathrm{ml}$ of ethanol) then shaken. Erlenmeyer was then stored in the dark for 45 minutes while several times shaken and added $7 \mathrm{~mL}$ of $30 \%$ $\mathrm{KI}$ and $50 \mathrm{ml}$. The solution was titrated using a $0.1 \mathrm{~N}$ $\mathrm{Na}_{2} \mathrm{~S}_{2} \mathrm{O}_{3}$ solution with a $1 \%$ starch indicator. The titration end point is marked by the loss of blue; the same way is done for the empty one. The iodine number is determined by the following equation:

$$
\text { Iodine Value }=\frac{12,69 \times(B-C) \times N}{W}
$$

Where; $B$ is volume of empty solution $\mathrm{Na}_{2} \mathrm{~S}_{2} \mathrm{O}_{3}[\mathrm{ml}]$, $C$ is volume of sample solution $\mathrm{Na}_{2} \mathrm{~S}_{2} \mathrm{O}_{3}$ [ml], $N$ is normality of solution $\mathrm{Na}_{2} \mathrm{~S}_{2} \mathrm{O}_{3}, W$ is sample weight [gr].

Saponification Value: is the oil content that forms the soap when mixed with an alkaline solution. The testing of soap number was done by AOCS Cd 3-25 method. 0.5 gram samples were fed into the Erlenmeyer flask, added $5 \mathrm{ml}$ of $\mathrm{KOH}$ methanol solution (20 gr $\mathrm{KOH}$ in $500 \mathrm{ml}$ of methanol). The mixture was refluxed for $30 \mathrm{~min}$, at $70^{\circ} \mathrm{C}$ while stirring. The reflux results were cooled and the pp 3 $\mathrm{ml}$ indicator added, and then titrated with $0.45 \mathrm{~N} \mathrm{HCl}$ solutions. To know $\mathrm{KOH}$ excess is done with empty titration.

$$
S V=\frac{(b-c) x N \mathrm{HCl} \times \mathrm{BM} \mathrm{KOH}}{\text { weight of sample }(g r)}
$$

Where; $b$ is a volume of $0.45 \mathrm{~N} \mathrm{HCl}$ in an empty titration, $c$ is a volume of $0.45 \mathrm{~N} \mathrm{HCl}$ in the sample titration.

Un-saponification matter: is the content of an oil that does not form soap when mixed with an alkaline solution. Testing of un-saponification matter using AOCS Ca 6a-40 method.

Weight in grams of free fatty acids in the extract as oleic acid $=0,282 V N$. Where; $V$ is the volume in $\mathrm{ml}$ of potassium hydroxide standard, $N$ is normality of potassium hydroxide standard.

$$
U M=\frac{B-A}{W \text { in } g r} \times 100 \%
$$

where; $A$ is the residual weight [gr], $B$ is the weight of free fatty acid extract [gr], $W$ is the weight of the sample [gr].

\section{Result and Discussion}

\subsection{POME Characteristic}


The results of the waste characteristic analysis of each POME pond can be seen in table 2. It appears that the four ponds have a $\mathrm{pH}$ value range of 2.9-3.5. Although, there is a reduction of acidity level of wastewater from pond to pond, but it is still below the environmental quality standard threshold. The acidity of this liquid waste can cause the growth of organic content in the pond and low $\mathrm{pH}$ wastewater is recognized to have direct effect on soil chemical properties. It affects supply of mineral macro and micro nutrients for plant growth, soil $\mathrm{pH}$ and soil buffer capacity [21].

Table 2. Result of Waste Water Analysis

\begin{tabular}{lcccc}
\hline \multirow{2}{*}{ Parameter } & \multicolumn{4}{c}{ Result } \\
\cline { 2 - 5 } & Pond \#1 & Pond \#2 & Pond \#3 & Pond \#4 \\
\hline pH & 2.9 & 3.4 & 3.5 & 3.5 \\
Temp. $\left({ }^{\circ} \mathrm{C}\right)$ & 59.3 & 44.3 & 36.3 & 33.3 \\
BOD $_{5}(\mathrm{mg} / \mathrm{L})$ & $29,333.3$ & 25,625 & $39,616.7$ & 36,475 \\
$\mathrm{COD}(\mathrm{mg} / \mathrm{L})$ & $117,333.3$ & 106,000 & $146,333.3$ & $122,541.7$ \\
$\mathrm{TSS}(\mathrm{mg} / \mathrm{L})$ & $54,166.7$ & $65,833.3$ & $399,666.7$ & $182,666.7$ \\
Oil\&grease $_{(\mathrm{mg} / \mathrm{L})}$ & 6 & 3.3 & $<2$ & $<2$ \\
$\mathrm{NH}^{+}(\mathrm{mg} / \mathrm{L})$ & 3.5 & 4.0 & 10.6 & 4.7 \\
\hline
\end{tabular}

Based on the analysis, the value of BOD and COD in table 2 are increasing from pond \#1 to pond \#4. BOD and COD figures are important parameters in waste water quality standards. If there is a large quantity of organic waste in the water supply, there will also be a lot of bacteria present working to decompose this waste. In this case, the demand for oxygen will be high (due to all the bacteria) so the BOD level will be high. As the waste is consumed or dispersed through the water, BOD levels will begin to decline [22].

Chemical oxygen demand (COD) is one of the most important parameters and has been widely employed for water quality assessment. Because the degradation of organic compounds requires oxygen, the quantity that they are present in a water sample can be estimated by the amount of oxygen necessary for their oxidation. Thus, COD was preferred for estimating organic pollution of water [23]. If the BOD and COD values are very high, this indicates that microbiological and organic processes can cause environmental pollution, if not further processed. One of the problems caused is turbidity and a sharp odor that can damage the aquatic ecosystem.

Oil and POME solids tend to accumulate at the bottom of the pond. Meanwhile, mud and water will gather in the pond. Deposition of solids into the pond body could lead to the reduction in the volume of the water and also impede the free flow of the pond [24]. Determination of total solid sludge (TSS) is useful to know the effect of domestic waste water pollution. If not further processed, POME will break down and form ammonia. Ammonia will affect the life of aquatic biota and cause a foul odor [25].

The management of palm oil mill only processed POME by relying on reservoir ponds as described in fig. 1. This treatment is done to fulfill the quality standard requirement of waste water, so that the waste water that flowed into the river has fulfilled the requirement as clean water. This management technique should be replaced by direct way to process the liquid waste into biodiesel raw materials.

\subsection{Composition of POME}

Determination of water content, Oil, Sediment, and sludge done when pre-treatment has not been carried out. If the value of this composition does not reach $100 \%$, there may still be other content that is not detected.

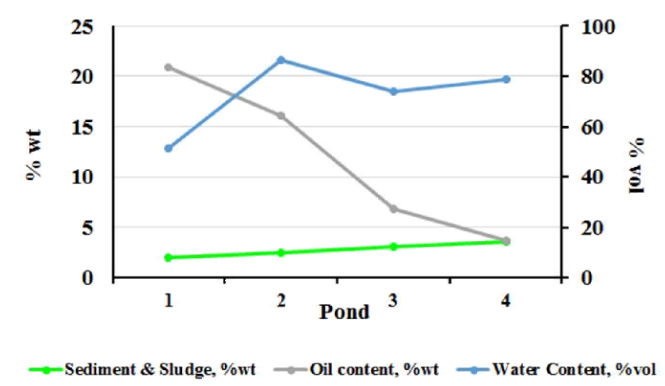

Fig. 5. Composition of POME

Fig.5 explains that in pond \#1, oil content reaches $21 \%$, water content $51 \%$ and sludge and sediment $2 \%$. The farther the pond from the palm oil mill, the less oil content, so that the water content and sludge and sediment is getting bigger.

\subsection{Oil Losses and its Compound}

Oil losses is recovered oil from POME. The quality of oil losses describe in Fig. 8, 10 and 11. There amount of oil losses where can be found in POME [26]. Table 2 shows that in the first pond has $6 \mathrm{mg} / \mathrm{L}$ of oil and grease. Therefor it's a necessity to found the oil losses in POME. From the pre-treatment results, the amount of oil losses in 1 liter of POME is shown in Fig. 6 below.

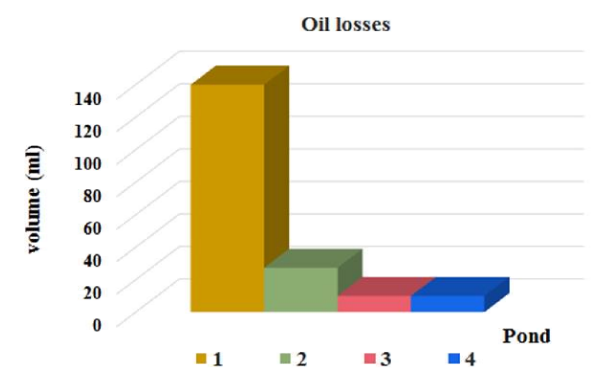

Fig. 6. Volume of oil losses

Vegetable oils derived from oil losses usually contain of carboxylic acids that have high boiling point as they can form hydrogen bonds with water. One of the important chemical properties of carboxylic acid is able to react with alcohol and produced an ester. From analytical analysis using IR 
Spectra, Fig. 7 describes the presence of carboxylic acid functional groups in oil losses.

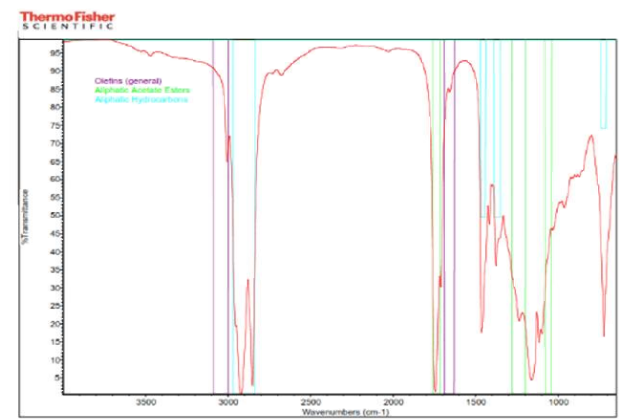

Fig. 7. Carboxylic acid groups

\subsection{Oil losses Characteristic}

The value characteristics of FFA, TAN, Kinematic viscosity, Iodine Value, Saponification value and Unsaponification Matter were performed after pretreatment separation of the oil losses from POME. Fig. 8 shows FFA and TAN values rise equal from pond 1 to pond 4. If FFA and TAN value are high it can occur of blocking where methanol which should be react with triglyceride hindered by soap formation.

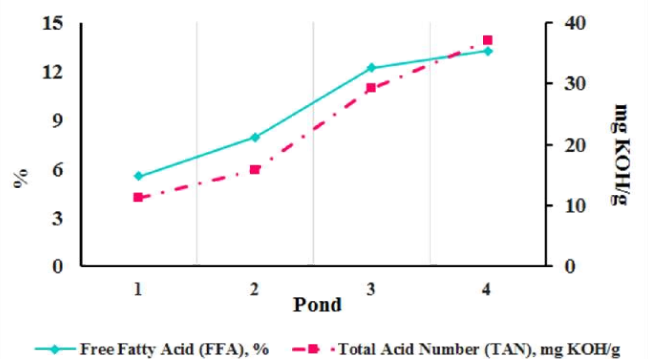

Fig. 8. Free Fatty Acid and Acid Number

From fig. 8 and fig.9 the FFA, TAN, sapponification and unsapponification matter values from the pond to the pond show an increase. Sapponification and unsaponification matter will be determine when the oil will be produced into biodiesel. The melting point of oil losses is around $33-39{ }^{\circ} \mathrm{C}$, where its freezing point is around $24.1{ }^{\circ} \mathrm{C}$ [26].

If FFA and TAN are high, saponification value is high, too [27]. If saponification value is high, the freezing process in the oil will be faster, the quality of the oil becomes bad. Takes longer time if it wants to be processed into Biodiesel because it has to lower the FFA and TAN first [28].

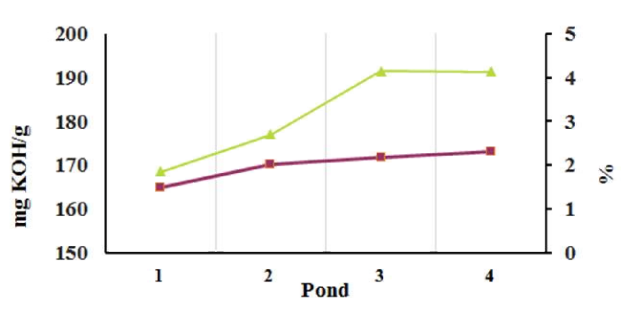

$\rightarrow$ Saponification Value, mg KOH/g $\quad-\lll-$ Unsapon ification Matter, $\%$

Fig. 9. Sapponification Value \& Unsaponification Matter

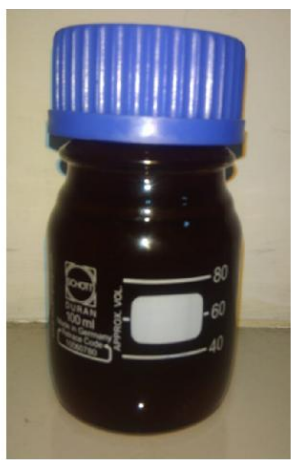

(a)

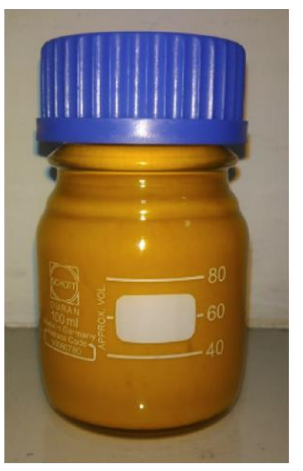

(b)
Fig. 10. Oil losses; (a) at $100^{\circ} \mathrm{C}$, (b) at room temperature $\left(20^{\circ} \mathrm{C}\right)$

Fig. 10 is the separated oil losses from POME. Fig. 10(a) is a condition of oil losses at $100{ }^{\circ} \mathrm{C}$ and picture 10(b) condition of oil losses at room temperature $\left(20{ }^{\circ} \mathrm{C}\right)$. At room temperature the oil losess becomes solid because it has high saponification value. If saponification higher the oil losses will quickly freeze. Oil losses frozen occurred starting from the pond \#2, \#3 and \#4. While the pond \#1 condition is still liquid.

The viscosity value in Fig. 11 shows that in pond 4 has decreased. This results in an extrapolation of viscosity values at temperature of $50{ }^{\circ} \mathrm{C}$ and $100{ }^{\circ} \mathrm{C}$.

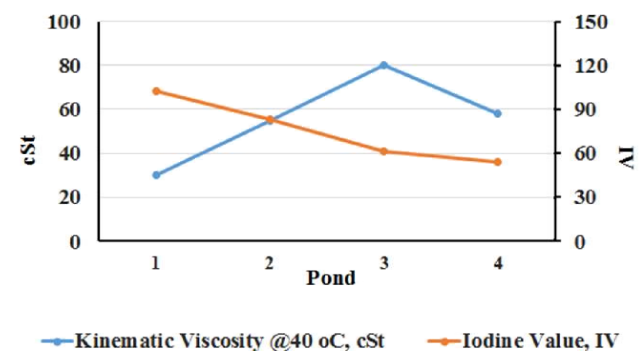

Fig. 11. Kinematic Viscosity dan Iodine Value

Iodine value (IV) is used as a parameter in process control as well as a quality parameter in traded palm oil products. Therefore, IV analysis is a routine activity in the palm oil industry [29]. IV depends on the value of the unsaturated fatty acids in the oil. If IV is low, the saturated fatty acids is high and the oil will 
freeze. If IV is high, the saturated fatty acid is low and the oil will be liquid. Fig. 11. shows that the lower of IV, Kinematic Viscosity is higher and flowrate is slower. It can be depreciation on engine components [30].

\section{Conclusion}

From the result of research and explanation above, it is found that POME characteristic from each pond does not fulfill the Ministry of Environment and Forestry's regulation No.5/2014 about waste water quality standard.

The oil and grease content in each pond explains that the oil losses obtained from POME have potential as a source of energy, especially for biodiesel source. Actually that the characteristics of POME and its oil losses are the fraction of oil wasted from Crude Palm Oil (CPO) processing, whereas CPO has characteristics as a raw material for biodiesel.

The first pond has the highest oil composition and characteristics of the results proved that the oil potential of these losses can be processed directly into biodiesel.

With their potential as raw material for biodiesel, palm oil industry has the opportunity to process the oil losses. The benefit that the waste water treatment system from Palm Oil Mill does not requires a big land for POME's ponds to achieve an environmentally friendly of palm oil agro-industry.

The change of paradigm of sustainable and environmentally friendly palm management is an effort to gain added value of economic in addition to CPO production capability that has been undertaken by the industry.

Many thanks to Mr. R. Boedhijono Martohandoko as Director of PT. Petrolab Services for support all of property to the researchers.

\section{References}

[1] E. Hambali, Rivai, "The Potential of Palm Oil Waste Biomass in Indonesia in 2020 and 2030 The Potential of Palm Oil Waste Biomass in Indonesia in 2020 and 2030," IOP Conf. Ser. Earth Enviromental Sci., vol. 65, no. 012050, 2017.

[2] P. Manajemen, T. Pengolahan, L. Cair, P. Kelapa, and R. C. Npm, "Limbah Cair Sebagai Bahan Baku Pembangkit Listrik Kelapa sawit (Elaeis)” pp. 1-13, 2014.

[3] Hidayat, A., Mukti, N.I.F., Handoko, B., Sutrisno, B., 2018. Biodiesel Production from Rice Bran Oil over Modified Natural Zeolite Catalyst. International Journal of Technology. Volume 9(2), pp. 400-411.
[4] Nur, S. M., and J. Jusri. Übah Paradigma Agroindustri

Sawit Menuju Energi Terbarukan, 2014.

[5] M. A. Ngan, Y. Tajima, M. Asahi, and J. Hanif, "A novel treatment for palm oil mill effluent," Palm Oil Res Inst Malaysia (PORIM) Technology, vol. 19. pp. 1-8, 1996.

[6] M. Lingkungan and H. Republik, "Salinan - 1 -," pp. 1-83, 2014.

[7] A. L. Ahmad, C. Y. Chan, S. R. Abd Shukor, and M. D. Mashitah, "Recovery of oil and carotenes from palm oil mill effluent (POME)," Chem. Eng. J., vol. 141, no. 1-3, pp. 383-386, 2008.

[8] S. R. Putri Primandari, Z. Yaakob, M. Mohammad, and A. B. Mohamad, "Characteristics of residual oil extracted from palm oil mill effluent (POME)," World Appl. Sci. J., vol. 27, no. 11, pp. 1482-1484, 2013.

[9] A. Hayyan, M. A. Hashim, and M. Hayyan, "Application of a Novel Catalyst in the Esterification of Mixed Industrial Palm Oil for Biodiesel Production," Bioenergy Res., vol. 8, no. 1, pp. 459-463, 2015.

[10] A. Sundaryono, "Karakteristik Biodiesel dan Blending

Biodiesel dari Oil Losses Limbah Cair

Pabrik Minyak

Kelapa Sawit,” vol. 2041, 2010.

[11] A. Hayyan et al., "Reduction of high content of free fatty acid in sludge palm oil via acid catalyst for biodiesel production," Fuel Process. Technol., vol. 92, no. 5, pp. 920924, 2011.

[12] A. Hayyan, M. Z. Alam, and S. Mirghani, M E S., Kabbashi, N A., Hakimi, N I N M., Siran, Y M., Tahiruddin, "Production of Biodiesel from Sludge Palm Oil by Esterification Process," Energy power Eng., vol. 4, no. 1, pp. 11-17, 2010.

[13] A. Hayyan et al., "Sludge palm oil as a renewable raw material for biodiesel production by two-step processes," Bioresour. Technol., vol. 101, no. 20, pp. 7804-7811, 2010.

[14] Z. Mohamad and W. J. Yahya, "Biofuels from an Esterification of Sludge Palm Oil as an Alternative to Residual Oil," Adv. Mater. Res., vol. 512-515, pp. 1858-1861, 2012.

[15] R. R. Nasaruddin, M. Z. Alam, and M. S. Jami, "Evaluation of solvent system for the enzymatic synthesis of ethanol-based biodiesel from sludge palm oil (SPO)," Bioresour. Technol., vol. 154, pp. 155-161, 
2014.

[16] "Penggunaan n-heksana Sebagai Pelarut Untuk Memisahkan Minyak Sawit dari Sludge Heavy Phase

Menggunakan Metode Estraksi Cair Cair”.

[17] A. L. Ahmad, K. Sithamparam, M. M. D. Zulkali, S. Ismail, E. Campus, and S. Ampangan, "Extraction of Residue Oil From Palm Oil Mill Effluent ( Pome ) Using Organic Solvent," vol. 20, pp. 385-394, 2003.

[18] J. DeRuiter, "Carboxylic Acid Structure and Chemistry: Part 1," Princ. Drug Action 1, pp. 1-11, 2005.

[19] N. Erinda, "Universitas Sumatera Utara," pp. $1-2,2011$

[20] University of California, "IR Spectra: Tricks for Identifying the 5 Zones," pp. 1-7, 2013.

[21] M. J. Mohammad Rusan, S. Hinnawi, and L. Rousan, "Long term effect of wastewater irrigation of forage crops on soil and plant quality parameters," Desalination, vol. 215, no. 1-3, pp. 143-152, 2007.

[22] Unknown, "Biological Oxygen Demand ( BOD ) - Overview," pp. 3-21, 1988.

[23] J. D. Bala, J. Lalung, and N. Ismail, "Palm Oil Mill Effluent (POME) Treatment “"Microbial Communities in an Anaerobic Digester": A Review," Int. J. Sci. Res. Publ., vol. 4, no. 6, pp. 1-24, 2014.

[24] T. J. K. Ideriah, P. U. Adiukwu, and H. Stanley, "Medwell Journals, 2007," pp. 842 $845,2007$.

[25] A. Lestari, A. Ahmad, and I. Zahrina, "Penyisihan Chemical Oxygen Demand ( COD ) Limbah Cair," 1995.

[26] M. E. Pome, I. Mob, and H. Sbi, "Waste management: bio-fuel recovery from palm oil mill effluent (pome)," 2013.

[27] M. M. Zamberi and R. Ayob, "Experimental Study on Low Cost Biodiesel Production Alkaline Based Catalysts by Using Frying Oil,” J. Eng. Technol., vol. 2, no. June, pp. 55-66, 2011.

[28] "Bioconversion energy," Fuel Energy Abstr., vol. 43, no. 5, pp. 331-335, 2002.

[29] T. Haryati, Y. B. Che Man, A. Asbi, H. M. Ghazali, and L. Buana, "Determination of iodine value of palm oil by differential scanning calorimetry," J. Am. Oil Chem. Soc., vol. 74, no. 8, pp. 939-942, 1997.

[30] J. Methyl, B. Ester, and H. Prasutiyon,
"Pengaruh Angka Iodin Terhadap Ketahanan Komponen- Komponen Utama Motor Diesel Dengan Bahan Bakar," 2017. 